ORIGINAL RESEARCH ARTICLE

\title{
Organ Transplantation and Organ Donation: Knowledge, attitude and willingness towards organ donation among medical students
}

\author{
Jyotsna Deshmukh ${ }^{1}$, Anchlesh Tekam², Kanchan Ingle ${ }^{3}$
}

\begin{abstract}
Affiliation: ${ }^{1}$ Associate Professor \& ${ }^{2}$ Junior Resident, Department of community medicine, Indira Gandhi Government
\end{abstract} Medical College Nagpur. ${ }^{3}$ Assistant Professor, Vihangi Nitnaware, NMIMS Mumbai.

*Author for correspondence: Dr. Anchlesh Tekam, Junior Resident, Department of community medicine, Indira Gandhi Government Medical College Nagpur. ${ }^{3}$ Assistant Professor, Vihangi Nitnaware, NMIMS Mumbai. email: anchalesh1987@gmail.com

$\begin{array}{ll}\text { Date of Submission } & : 11.02 .2020 \\ \text { Date of Acceptance } & : 20.03 .2020\end{array}$
Date of online Publication

Date of Print Publication
$: 31-03-2020$
$: 31-03-2020$

\section{AbSTRACT}

Introduction -: Organ transplant gives thousands of children and adults each year a renewed chance at living full and active lives. Though organ donation is a very noble thing to do but still there a huge gap of organ donors in the world. There is a long waiting lists of patients in the world. Objectives -: This study aims to assess and compare the knowledge, attitude and practices of medical students regarding organ donation. Methods -: Cross-sectional study was conducted in students of Indira Gandhi Government Medical College, Nagpur of Central India. Materials and Methods: A questionnaire adapted to the study requirements from the published research was designed to assess the knowledge attitude and practices toward organ donation. Students from the First Year, Second Year, Third Year (part-1\&2), Interns and post graduate students were included in the study. A total of 435 students filled the questionnaire. The scoring of the students was done out of 100 in every domain and a total score out of 100 was calculated by taking the mean of the scores of all the domains. The scores were classified into 0-50, 51-75 and 76-100. Results -: In knowledge 30.80\% of the medical students scored more than 75 . In attitude, $71.26 \%$ of the medical students scored more than 75 . But in Practices, only $4.59 \%$ of students scored more than 75. Conclusions -: Though the knowledge and attitude scores are high in medical students, but the practice score is still low.

Key word: organ donation, Organ transplantation, medical students

\section{INTRODUCTION}

Medical sciences have made great strides in last few decades and amongst them organ transplantation has been a major advancement which has resulted in new a lease of life for large number of patients. Organ donation is the donation of biological tissue or an organ of the human body from a living or dead person to a living recipient in need of a transplantation(1). According to research done by a Non-Governmental Organization (NGO), it was found that in India nearly 1.5 lakh people require a kidney transplant for their survival but only 3000 of them receive one and the rest of them lose their life waiting for their turn. The liver transplant requirement is around 25000 but we manage to achieve only about 800 . Hence, the waiting list for organ transplantation is exponentially increasing day by day(2). Addressing the widening gap between the demand and supply for organ donation has become an important public health problem globally and India is no exception to that. The awareness regarding voluntary blood donation is satisfactory among our people, pledging for the donation of organs after death lacks prominence in our country. The organ donation rate of 0.26 per million in India is poor compared with America 26, Sweden 35.3 and Croatia 36.5 per million(3). Human organ donation was legalized in India since 1994 through 'The transplantation of Human Organs Act, 1994'. Even after 18 years, the country passed the Transplantation of Human Organs Act 1994, only kidney donations by live donors are in vogue - cadaver donations have still not picked up (4).

At present, most organs for transplants come from living donors; legally these donors can only be the immediate family. As a result, only a small percentage of organ seekers can find compatible and keen donors. Another alternative is deceased donation where organs are retrieved from a person declared brain dead. Due to the extremely low number of deceased donations, most people awaiting transplant breathe their last (5). 
Jyotsna Deshmukh. et al. Organ Transplantation and Organ Donation.

Doctors and nurses are in regular contact with patients and could play a major role in promoting organ donation, and they may influence the decision making by the rest of the population; any unfavorable attitude of this group would be an obstacle to an increase in organ transplantation. Motivation to donate has been associated with the appropriate awareness of organ donation; most of the research on this subject came from developed countries(6).

We aimed in this study to assess the knowledge, attitude, and practices of the medical students in the medical college towards organ donation and organ transplantation.

\section{MATERIALS}

Our study aimed to analyze knowledge, attitude and willingness on organ donation and organ transplantation among the students of Indira Gandhi Government Medical College, a tertiary care hospital in Nagpur, Central India. It was a cross-sectional study done from June 2018 to August 2018. The first, second, third (part 1 \&2) year students of M.B.B.S, Interns and Resident Doctors (post Graduates students) participated in the study. A total of 435 students who were willing to participate were included in this study. Each study participant has explained the nature and purpose of this study and their consent was obtained. The participation in the study was voluntary and details of the participants were kept confidential.

A 28 item structured, self-administered questionnaire adapted to the study requirements from the previous published research articles was designed to assess the knowledge attitude and practices towards organ donation. The questionnaire was distributed to undergraduate dental students during lecture hours in the classroom. The participants were instructed not to discuss the questions among themselves. Only completed questionnaires were utilized for the study.

The questionnaire included four sections: -

Section A: The first section of the questionnaire gathered the socio-demographic details from the students, which included age, gender and year of education.

Section B: The second section intended to assess the levels of knowledge about organ donation (Question 114). This sections included the questions regarding participant's awareness about organ donation, organ transplantation, human transplantation act, brain death, organ donation process and medical compatibility for organ donation.

Section C: The third section assessed the attitude towards organ donation (Question 15-25). This section included the questions about the attitude of students such as "do you support organ donation?" ; “does your religion agree with organ donation and transplantation?" etc.
Section D: The fourth section assessed participant's willingness to donate organs (Question 26-28). This section included the questions about the practice of students such as "have you pledged to donate an organ?" ; "do you carry an organ donation card?".

Scoring - Every right answer was given 1 score (no negative marking) and the summed score of every domain (Knowledge, Attitude, Practice) was transformed into out of 100 scores. The scores were graded as $0-50=$ POOR, 51-75 = FAIR and 76-100 = GOOD. Higher scores indicate higher level of knowledge, positive attitude and good practice habits towards organ donation.

Statistical Analysis: - Data were analyzed using Microsoft Excel and Epi Info software, by Pearson Chisquare test, t-test and ANOVA were used for comparing means of normally distributed continuous variables.

\section{RESULTS}

In the study, 435 students participated. The mean age of the participants was $22.24 \pm 2.88$ years. $208(47.81 \%)$ were female and $227(52.19 \%)$ were male subjects. According to educational level, 63(14.48\%) were from the first year, $82(18.85 \%)$ from the second year, $69(15.86 \%)$ from third year part-1, 68(15.64\%) from third year part-2, 83(19.08\%) were doing Internship and $70(16.09 \%)$ were postgraduate students.

Table no.1 showing association of educational level and gender with knowledge.

\begin{tabular}{|c|c|c|c|c|c|}
\hline \multirow{2}{*}{ Variables } & \multicolumn{3}{|c|}{$\begin{array}{c}\text { Knowledge Scores out of } \\
100\end{array}$} & \multirow{2}{*}{ Total } & \multirow{2}{*}{$\begin{array}{l}\text { Chi- } \\
\text { square }\end{array}$} \\
\hline & POOR & FAIR & GOOD & & \\
\hline \multicolumn{6}{|c|}{ Educational Level } \\
\hline First Year & 36 & 15 & 12 & 63 & \multirow{7}{*}{$\begin{array}{c}\chi^{2}= \\
129.94 \\
\text { d.f. }=5 \\
\text { p value } \\
<0.00\end{array}$} \\
\hline $\begin{array}{l}\text { Second } \\
\text { Year }\end{array}$ & 25 & 41 & 16 & 82 & \\
\hline $\begin{array}{l}\text { Third Year } \\
\text { Part } 1\end{array}$ & 24 & 31 & 14 & 69 & \\
\hline $\begin{array}{l}\text { Third Year } \\
\text { part } 2\end{array}$ & 21 & 32 & 15 & 68 & \\
\hline Interns & 11 & 49 & 23 & 83 & \\
\hline $\begin{array}{l}\text { Post- } \\
\text { Graduation }\end{array}$ & 1 & 5 & 64 & 70 & \\
\hline Total & 123 & 178 & 134 & 435 & \\
\hline \multicolumn{6}{|l|}{ Gender } \\
\hline Female & 44 & 94 & 70 & 208 & \multirow{3}{*}{$\begin{array}{c}\chi^{2}=1.51 \\
\text { d.f. }=1 \mathrm{p} \\
\text { value }=0.21\end{array}$} \\
\hline Male & 79 & 84 & 64 & 227 & \\
\hline Total & 123 & 178 & 134 & 435 & \\
\hline
\end{tabular}


Jyotsna Deshmukh. et al. Organ Transplantation and Organ Donation.

To assess the knowledge of the subjects 14 questions were used. The scores were classified as poor, fair and good. 123(28.28\%) were in poor, 178(40.92\%) were in fair and $134(30.81 \%)$ subjects were in a good category. Further, the association between educational level and knowledge was statistically significant (Table No.1). The knowledge scores were higher in postgraduates and interns as compared to the undergraduate students. There was no significant difference in the performance of the male and female students.

Table no.2 showing association of educational level and gender with attitude.

\begin{tabular}{|c|c|c|c|c|c|}
\hline \multirow{2}{*}{ Variables } & \multicolumn{3}{|c|}{ Attitude Scores out of 100} & \multirow{2}{*}{ Total } & \multirow{2}{*}{$\begin{array}{l}\text { Chi- } \\
\text { square }\end{array}$} \\
\hline & POOR & FAIR & GOOD & & \\
\hline \multicolumn{6}{|c|}{ Educational Level } \\
\hline First Year & 2 & 20 & 41 & 63 & \multirow{7}{*}{$\begin{array}{c}\chi 2=34.32 \\
\text { d.f. }=5 \mathrm{p} \\
\text { value } \\
<0.00\end{array}$} \\
\hline $\begin{array}{l}\text { Second } \\
\text { Year }\end{array}$ & 3 & 30 & 49 & 82 & \\
\hline $\begin{array}{l}\text { Third Year } \\
\text { Part } 1\end{array}$ & 1 & 29 & 39 & 69 & \\
\hline $\begin{array}{l}\text { Third Year } \\
\text { part } 2\end{array}$ & 0 & 21 & 47 & 68 & \\
\hline Internship & 2 & 13 & 68 & 83 & \\
\hline $\begin{array}{l}\text { Post- } \\
\text { Graduation }\end{array}$ & 1 & 4 & 65 & 70 & \\
\hline Total & 9 & 116 & 310 & 435 & \\
\hline \multicolumn{6}{|l|}{ Gender } \\
\hline Female & 7 & 49 & 152 & 208 & \multirow{3}{*}{$\begin{array}{l}\chi 2=0.63 \\
\text { d.f. }=1 \mathrm{p} \\
\text { value }=0.42\end{array}$} \\
\hline Male & 2 & 67 & 158 & 227 & \\
\hline Total & 9 & 116 & 310 & 435 & \\
\hline
\end{tabular}

\# POOR AND FAIR groups were clubbed together and compared against GOOD.

Table no.2 showing association of educational level and gender with attitude.

\begin{tabular}{|c|c|c|c|c|c|}
\hline \multirow{2}{*}{ Variables } & \multicolumn{3}{|c|}{ Attitude Scores out of 100} & \multirow{2}{*}{ Total } & \multirow{2}{*}{$\begin{array}{l}\text { Chi- } \\
\text { square }\end{array}$} \\
\hline & POOR & FAIR & GOOD & & \\
\hline \multicolumn{6}{|c|}{ Educational Level } \\
\hline First Year & 2 & 20 & 41 & 63 & \multirow{7}{*}{$\begin{array}{c}\chi^{2}=34.32 \\
\text { d.f. }=5 \mathrm{p} \\
\text { value }<0.0\end{array}$} \\
\hline $\begin{array}{l}\text { Second } \\
\text { Year }\end{array}$ & 3 & 30 & 49 & 82 & \\
\hline $\begin{array}{l}\text { Third Year } \\
\text { Part } 1\end{array}$ & 1 & 29 & 39 & 69 & \\
\hline $\begin{array}{l}\text { Third Year } \\
\text { part } 2\end{array}$ & 0 & 21 & 47 & 68 & \\
\hline Internship & 2 & 13 & 68 & 83 & \\
\hline $\begin{array}{l}\text { Post- } \\
\text { Graduation }\end{array}$ & 1 & 4 & 65 & 70 & \\
\hline Total & 9 & 116 & 310 & 435 & \\
\hline \multicolumn{6}{|l|}{ Gender } \\
\hline Female & 7 & 49 & 152 & 208 & \multirow{3}{*}{$\begin{array}{l}\chi^{2}=0.63 \\
\text { d.f. }=1 \mathrm{p} \\
\text { value }=0.42\end{array}$} \\
\hline Male & 2 & 67 & 158 & 227 & \\
\hline Total & 9 & 116 & 310 & 435 & \\
\hline
\end{tabular}

\# POOR AND FAIR groups were clubbed together and compared
Table no.3 showing association of educational level and gender with practices.

\begin{tabular}{|c|c|c|c|c|c|}
\hline \multirow{2}{*}{ Variables } & \multicolumn{3}{|c|}{$\begin{array}{c}\text { Practices Scores out of } \\
100 \\
\end{array}$} & \multirow[t]{2}{*}{ Total } & \multirow[t]{2}{*}{ Chi- square } \\
\hline & POOR & FAIR & GOOD & & \\
\hline \multicolumn{6}{|c|}{ Educational Level } \\
\hline First Year & 52 & 4 & 7 & 63 & \multirow{7}{*}{$\begin{array}{c}\chi 2=4.76 \\
\text { d.f. }=5 p \\
\text { value }=0.44\end{array}$} \\
\hline $\begin{array}{l}\text { Second } \\
\text { ar }\end{array}$ & 74 & 4 & 4 & 82 & \\
\hline $\begin{array}{l}\text { Third Year } \\
\text { Part } 1\end{array}$ & 61 & 7 & 1 & 69 & \\
\hline $\begin{array}{l}\text { Third Year } \\
\text { part } 2\end{array}$ & 59 & 5 & 4 & 68 & \\
\hline Internship & 67 & 14 & 2 & 83 & \\
\hline $\begin{array}{l}\text { Post- } \\
\text { Graduation }\end{array}$ & 57 & 11 & 2 & 70 & \\
\hline Total & 370 & 45 & 20 & 435 & \\
\hline \multicolumn{6}{|l|}{ Gender } \\
\hline Female & 180 & 16 & 12 & 208 & \multirow{3}{*}{$\begin{array}{c}\chi 2=0.68 \\
\text { d.f. }=1 \mathrm{p} \\
\text { value }=0.40\end{array}$} \\
\hline Male & 190 & 29 & 8 & 227 & \\
\hline Total & 370 & 45 & 20 & 435 & \\
\hline
\end{tabular}

Table no.4 showing the comparison of domain score means for educational level and gender.

\begin{tabular}{|c|c|c|c|c|}
\hline Variables & No. & Knowledge & Attitude & Practices \\
\hline \multicolumn{5}{|c|}{ Educational Level } \\
\hline First Year & 63 & $53.96 \pm 18.62$ & $76.91 \pm 13.54$ & $27.51 \pm 32.53$ \\
\hline $\begin{array}{l}\text { Second } \\
\text { Year }\end{array}$ & 82 & $60.27 \pm 16.61$ & $77.60 \pm 13.54$ & $18.29 \pm 26.78$ \\
\hline $\begin{array}{l}\text { Third Year } \\
\text { Part } 1\end{array}$ & 69 & $58.90 \pm 16.63$ & $77.14 \pm 13.76$ & $14.97 \pm 24.61$ \\
\hline $\begin{array}{l}\text { Third Year } \\
\text { part } 2\end{array}$ & 68 & $57.66 \pm 12.72$ & $81.61 \pm 11.47$ & $20.09 \pm 28.87$ \\
\hline Internship & 83 & $67.72 \pm 12.88$ & $84.83 \pm 13.87$ & $24.09 \pm 27.70$ \\
\hline $\begin{array}{c}\text { Post- } \\
\text { Graduation }\end{array}$ & 70 & $94.38 \pm 11.65$ & $90.77 \pm 10.43$ & $24.76 \pm 27.61$ \\
\hline \multicolumn{2}{|c|}{ ANOVA p value } & $<0.000$ & $<0.000$ & 0.091 \\
\hline \multicolumn{5}{|c|}{ Gender } \\
\hline Female & 208 & $67.61 \pm 18.70$ & $82.18 \pm 14.72$ & $20.35 \pm 28.70$ \\
\hline Male & 227 & $63.84 \pm 20.94$ & $80.97 \pm 12.80$ & $22.61 \pm 27.65$ \\
\hline \multicolumn{2}{|c|}{$\begin{array}{c}\text { Independent t Test } \\
\text { p value }\end{array}$} & 0.049 & 0.359 & 0.403 \\
\hline
\end{tabular}

To assess the attitude of the subjects 11 questions were used. The attitude scores were almost similar for interns and post graduate students. The male and females subjects got similar scores in attitude regarding organ donation. Comparison of positive attitude response based on education level revealed that $310(71.26 \%)$ had a good 
positive attitude. Only few $9(0.020 \%)$ had poor score for positive attitude. Statistically significant difference was found for the attitude score and educational level.

To assess the practices of the subjects 3 questions were used. Only $20(0.04 \%)$ had good scores for practice. These shows that there is a need to improve these domain. There was no difference between the genders for practice scores.

The mean knowledge and attitude score showed significant association with the educational level. But the mean practice score did not show any significant difference based on the education level. While the post graduate students reported better mean scores in knowledge and attitude compared to other medical students, first year students showed better mean practice score. Though there was significant difference in the knowledge scores of female as compared to males but in attitude and practices scores both the genders did not reveal any significant difference.

\section{DISCUSSION}

Organ transplantation is the most preferred treatment modality for the end stage organ disease and organ failure. The present cross-sectional study attempted to assess knowledge, attitude and practice of 435 medical students of Indira Gandhi Government Medical College Nagpur. The mean age of the study subject was found to be $22.24 \pm 2.88$ years. Various studies carried out by Chakradhar et al, Jothula KY et al, Deshpande et al on medical students found the mean age to be 19.6 \pm 1.7 years, $23.3 \pm 0.73$ years, 21.9 years respectively, which was similar to our findings $(8)(9)(10)$.

Shireen et al, Sahana et al, Meghana et al reported $49.5 \%$ males - $50.5 \%$ females, $48.2 \%$ males $-51.8 \%$ females, $58.6 \%$ males $-41.3 \%$ female respectively(11)(12)(13). Our study finding were similar to them with 208 $(47.81 \%)$ female and $227(52.19 \%)$ were male subjects. Darlington et al conducted a study on medical students found a significant difference in knowledge scores among different educational levels(14) which were similar to our study findings. Another study by Chakradhar et al found no significant difference amongst the educational levels(8).

Sucharitha et al and Agarwal et al showed that $97.2 \%$ and $100 \%$ of students knew the term "Organ Donation" respectively, which is similar to our finding i.e. $100 \%$ (15)(16). Gupta RK et al concluded that $81.07 \%$ subject already knew about the "Organ Transplant Act" which is higher than our study i.e. $65.7 \%$ (17). However, Bharambe VK et al and Annadurai et al reported a lower awareness about existing laws to the tune of $57.6 \%$ and $13.9 \%$ respectively (18)(19).

Majority of the participants (74\%) were aware that HLA compatibility is essential for organ donation. Uplap et al found that $64.41 \%$ of the participants were aware that
HLA compatibility is essential for organ donation (20). Whereas another study in Pakistan, 94.3\% of subjects considered HLA compatibility as important prerequisites for organ donation (21).

The attitude scores in our study were high, the majority of the subjects scored more than 75 , and $76.3 \%$ were willing to donate organs after death. Bilgel $\mathrm{H}$ et al, Kinge $\mathrm{A}$ et al, and Ibrahim $\mathrm{M}$ et al reported that $58.4 \%, 69.0 \%$ and $52.8 \%$ of subjects were willing to donate organs respectively $(22)(23)(24)$. Babaie et al concluded that $60.7 \%$ of subjects were willing to donate organs of their family/relatives after death (25). In our study, it was $49.9 \%$.

In our study $72.2 \%$ subjects did not perceive religion as barrier towards organ donation. Ibrahim $\mathrm{M}$ et al, Poreddi et al, and Oluyombo et al stated $83.0 \%, 59.9 \%$ and $63.4 \%$ of subjects had support from the religion towards organ donation respectively $(24)(26)(27)$.

Very few participant had cited fear of disfigurement after consenting to organ donation (10.6\%). However Bilgel $\mathrm{H}$ et al, Ibrahim $\mathrm{M}$ et al, and Poreddi et al reported relatively higher $17.1 \%, 12.0 \%$ and $19.1 \%$ of subjects have the fear of disfigurement after consenting to Organ Donation respectively $(22)(24)(26)$.

Meagre number of the post graduate students $(20 \%)$ in our study have ever counselled the patient for organ donation. In a study by Uplap et al $38.65 \%$ of postgraduate subjects have counseled the patients regarding Organ Donation(20). Only 6.4\% of participants have organ donation cards in our study. Soylar et al, Babaie et al, Uzuntarla et al concluded that possession of organ donation cards are $0.5 \%, 33.3 \%$ and $16.7 \%$ $(28)(25)(29)$.

Conclusion: - Though the medical students had fair knowledge about organ donation and transplantation they lacked in good practices. The topic of brain death and organ donation have part of medical undergraduate curriculum. Still it has not been sufficient to make them equipped with necessary skill. Innovative and sustainable efforts to create awareness among both the medical and general population should be developed.

Acknowledgement: - We like to acknowledge the efforts and the support of the medical students of IGGMCH, Nagpur for the completion of the study.

\section{REFERENCES}

1. WHO. Global Glossary of Terms and Definitions on Donation and Transplantation [Internet]. WHO. 2009. p. 15. Available from: http://www.who.int/transplantation/activities/en/

2. Mohan Foundation. Mohan Foundation. Organ donation and transplantation. [Internet]. Available from: https://www.mohanfoundation.org/

3. Ministry of Health and Family Welfare. National Organ and Tissue Transplant Organization. [Internet]. 
Available from: https://www.notto.gov.in/index.htm

4. Transplantation of human organs and tissues. [Internet]. Bulletin of medical ethics. 2003. p. 8-11. Available from: https://mohfw.gov.in/acts-rules-and-standardshealth-sector/acts/transplantation-human-organs-actsand-rules

5. organdonationday. http://organdonationday.in/about/why [Internet]. Available from: http://organdonationday.in/about/why

6. Flayou K, Kouam N, Miara H, Raoundi O, Ouzeddoun $\mathrm{N}$, Benamar L, et al. Attitudes toward organ donation among personnel from the University Hospital of Rabat. Saudi J Kidney Dis Transplant. 2016;27(4):758.

7. Dippold B. University of Pittsburgh. [Internet]. Vol. 64, Min Congr J. 1978. p. 40-2. Available from: https://www.irb.pitt.edu/content/research-involvingstudents-research-participants

8. Chakradhar K, Doshi D, Srikanth Reddy B, Kulkarni S, Padma Reddy M, Sruthi Reddy S. Knowledge, attitude and practice regarding organ donation among Indian dental students. Int $\mathbf{J}$ Organ Transplant Med. 2016;7(1):28-35.

9. Jothula KY, D. S. Study to assess knowledge, attitude and practice regarding organ donation among interns of a medical college in Telangana, India. Int J Community Med Public Heal. 2018;(March).

10. Deshpande PR, Damle P, Bihani G KS, Naik AN PA. Knowledge, Attitude, and Practice of Organ Donation among Pharmacy Students. Indian J Transplant. 2018;12:113-8.

11. Shireen N, Ansari MW IA, Selladurai S RS. Knowledge and Attitude about Organ Donation and Transplantation among Students of a Medical College in Kalaburagi. Natl J Community Med. 2018;9(4):278-82.

12. Sahana BN, Sangeeta M. Knowledge, Attitude and Practices of Medical Students Regarding Organ Donation. Res Artic Int $\mathbf{J}$ Cur Res Rev [Internet]. 2015;7(16):74-7. Available from: http://www.ijcrr.com/uploads/474_pdf.pdf

13. S. G. M, Subramanian M, Atmakuri SA, S. T, Bera P, J. N. A study on knowledge, attitude and practice regarding organ donation and transplantation among final year health science students in Bengaluru, Karnataka, India. Int J Community Med Public Heal. 2018;5(4):1529.

14. Darlington D, Anitha FS, Joseph C. Study of Knowledge, Attitude, and Practice of Organ Donation Among Medical Students in a Tertiary Care Centre in South India. Cureus. 2019;(June):0-9.

15. Sucharitha ST, Siriki R, Dugyala RR, Mullai P RK. Organ Donation: Awareness, attitudes and beliefs among undergraduate medical students in South India. Natl J Res Community Med. 2013;2(2):79-84.

16. Agarwal S. Are Medical Students Having Enough Knowledge about Organ Donation. IOSR J Dent Med Sci. 2015;14(7):29-34.

17. Gupta RK, Singh P, Akhtar N, Kumari R, Gupta C, Gupta R. Gender based perspectives about organ donation among students in a medical school in North India. Int J Res Med Sci. 2018;6(5):1710.

18. Bharambe VK, Rathod H AK. Knowledge and Attitude Regarding Organ Donation among Medical Students. BANTAO J. 2014;16(1):34-40.

19. Annadurai K, Mani K RJ. A study on knowledge, attitude and practices about organ donation among college students in Chennai, Tamil Nadu -2012. Prog Heal Sci. 2013;3(2):59-65.

20. Uplap PA, Singh R. Exploring scope for improvement in knowledge attitude and practices about organ, tissue donation and transplantation among postgraduate medical students in Mumbai, India. Int J Community Med Public Heal. 2016;4(1):229.

21. Ali NF, Qureshi A, Jilani BN ZN. Knowledge and ethical perception regarding organ donation among medical students. BMC Med Ethics. 2013;14(38).

22. Bilgel H, Sadikoglu G, Bilgel N. Knowledge and attitudes about organ donation among medical students. Transplantationsmedizin Organ der Dtsch Transplantationsgesellschaft. 2006;18(2):91-6.

23. Kinge A, Bhate K, Yadav A, Vyas P. Knowledge and Concerns for Organ Donation Amongst Nursing Students and Nursing Staff in an Apex Medical Institute in a Metropolitan City. J Evol Med Dent Sci. 2017;6(13):991-3.

24. Ibrahim M, Randhawa G. Knowledge, Attitudes, and Behavior of Nigerian Students Toward Organ Donation. Transplant Proc [Internet]. 2017;49(8):1691-7. Available from: http://dx.doi.org/10.1016/j.transproceed.2017.04.011

25. Babaie M, Hosseini M, Hamissi J, Hamissi Z. Knowledge, Attitude and Practice of Nurses Regarding Organ Donation. Glob J Health Sci. 2015;7(6):129-37.

26. Poreddi V, Katyayani B V., Gandhi S, Thimmaiah R, Badamath S. Attitudes, knowledge, and willingness to donate organs among Indian nursing students. Saudi J Kidney Dis Transpl. 2016;27(6):1129-38

27. R Oluyombo MF. Knowledge Regarding Organ Donation and Willingness to Donate among Health Workers in South-West Nigeria. Int J Organ Transplant Med. 2016;7(1):19-26.

28. Soylar P, Ulaş Kadioğlu B. Theology and Nursing Students' Knowledge of Organ Donation and Transplantation. Transplant Proc. 2018;50(10):2961-5.

29. Uzuntarla Y. Knowledge and Attitudes of Health Personnel About Organ Donation: A Tertiary Hospital Example, Turkey. Transplant Proc [Internet]. 2018;50(10):2953-60. Available from: https://doi.org/10.1016/j.transproceed.2018.08.004

\section{Conflict of Interest : None \\ Source of funding support : Nil}

(C) Community Medicine Faculties Association-2020

NJRCM: www.njircmindia.com www.commedjournal.in 